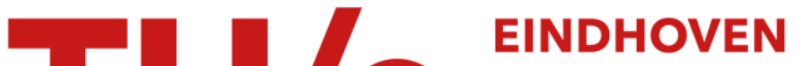 UNIVERSITY OF TECHNOLOGY
}

\section{Acoustical and optical characterization of air entrapment in piezo-driven inkjet printheads}

\section{Citation for published version (APA):}

Jong, de, J., Versluis, M., Bruin, de, G., Lohse, D., Reinten, H., Berg, van den, M., Wijshoff, H. M. A., \& Jong, de, N. (2005). Acoustical and optical characterization of air entrapment in piezo-driven inkjet printheads. In Proceedings of the 2005 IEEE International Ultrasonics Symposium, 18-21 September 2005, Rotterdam, The Netherlands (pp. 1270-1271). Institute of Electrical and Electronics Engineers.

https://doi.org/10.1109/ULTSYM.2005.1603083

DOI:

10.1109/ULTSYM.2005.1603083

Document status and date:

Published: 01/01/2005

\section{Document Version:}

Publisher's PDF, also known as Version of Record (includes final page, issue and volume numbers)

\section{Please check the document version of this publication:}

- A submitted manuscript is the version of the article upon submission and before peer-review. There can be important differences between the submitted version and the official published version of record. People interested in the research are advised to contact the author for the final version of the publication, or visit the $\mathrm{DOI}$ to the publisher's website.

- The final author version and the galley proof are versions of the publication after peer review.

- The final published version features the final layout of the paper including the volume, issue and page numbers.

Link to publication

\section{General rights}

Copyright and moral rights for the publications made accessible in the public portal are retained by the authors and/or other copyright owners and it is a condition of accessing publications that users recognise and abide by the legal requirements associated with these rights.

- Users may download and print one copy of any publication from the public portal for the purpose of private study or research.

- You may not further distribute the material or use it for any profit-making activity or commercial gain

- You may freely distribute the URL identifying the publication in the public portal.

If the publication is distributed under the terms of Article 25fa of the Dutch Copyright Act, indicated by the "Taverne" license above, please follow below link for the End User Agreement:

www.tue.nl/taverne

Take down policy

If you believe that this document breaches copyright please contact us at:

openaccess@tue.nl

providing details and we will investigate your claim. 


\section{Acoustical and Optical Characterization of Air Entrapment in Piezo-Driven Inkjet Printheads}

\author{
J. de Jong, M. Versluis, \\ G. de Bruin, D. Lohse \\ Faculty of Science and Technology \\ University of Twente \\ Enschede, The Netherlands \\ Email: d.lohse@utwente.nl
}

\author{
H. Reinten, M. van den Berg, \\ H. Wijshoff \\ Océ Technologies B.V., \\ Venlo, The Netherlands
}

\author{
N. de Jong \\ Exp. Echocardiography \\ Thoraxcentre, Erasmus MC, \\ Rotterdam, The Netherlands
}

\begin{abstract}
Air bubbles can cause nozzle failures in piezo-driven inkjet printheads [1]. The time development of the entrapped air bubbles has experimentally been studied [2]. It was found that the air bubble has a radius of $5 \mu \mathrm{m}$ just after the entrapment. The bubble then grows by rectified diffusion due to the applied pressure field, used for jetting droplets. Bjerknes forces drive the displacement of the air bubble. First, the bubble is pushed into the channel. After reaching the resonance size, given by the characteristic printhead frequency, the Bjerknes force reverses sign, pushing the air bubble towards the nozzle. At this time the air bubble has grown so large that it is not possible to jet it out, resulting in a nozzle failure.
\end{abstract}

\section{INTRODUCTION}

Air entrapment leads to malfunctioning of jet formation in a piezo-driven inkjet printhead. The entrapped air bubbles disturb the acoustics and in many cases cause the droplet formation to stop [1]. The nozzle diameter is $30 \mu \mathrm{m}$ or less. Droplets are jetted every $50 \mu \mathrm{s}$ and it is essential that the droplet formation remains stable for an extensive period. Though the droplet forming process is very stable for literally millions of droplets, from one to the next actuation cycle there may be an occurrence giving rise to a malfunctioning of the droplet formation. The time development of the entrapped air bubbles has experimentally been studied [2].

\section{Methods}

The acoustical signal is monitored by using the piezo actuator as a sensor to measure the pressure in the channel after the pulse is applied [1]. This signal is employed to monitor deviations in the droplet formation and to trigger the optical setup. In particular, it detects the presence of an air bubble inside the ink channel, as an air bubble modifies the acoustical signal in a characteristic way. The development of the acoustical signal after entrapment of an air bubble can be seen in figure 1, from [1]. The difference compared to the reference acoustical signal (i.e., the signal without air bubbles) is plotted.

The optical measurements are performed with a range of high speed imaging cameras up to $1 \mathrm{Mfps}$, including the Brandaris 128 camera system [3].

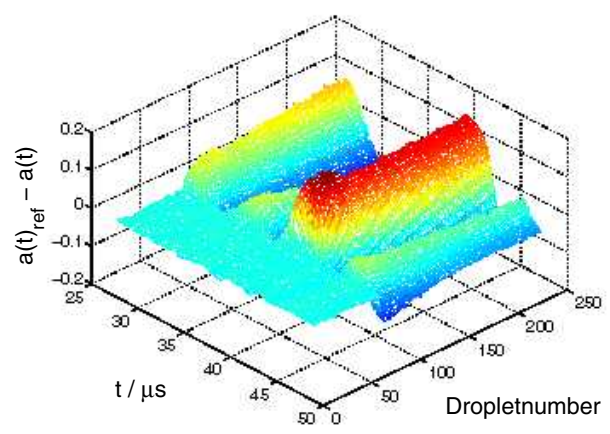

Fig. 1. Development of the acoustical signals, as compared to the reference signal without bubbles, after air bubble entrapment.

\section{BUBBLE DYNAMICS}

Once entrapped, the air bubble has an initial radius of $5 \mu \mathrm{m}$ and oscillates with a frequency near $200 \mathrm{kHz}$. Because of the acoustical field, the bubble oscillates. This oscillating causes a net growth of the bubble over an acoustical cycle. This process is called rectified diffusion [4], [5]. The radial growth of the bubble is found to be $0.3 \mu \mathrm{m} / \mathrm{ms}$ for $20 \mathrm{~ms}<t<60 \mathrm{~ms}$, as is shown in figure 2, from [2].

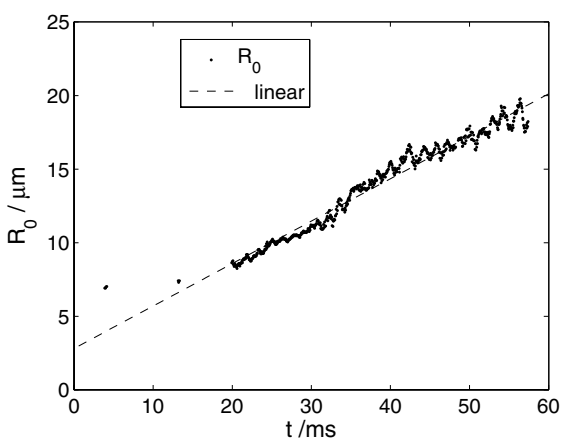

Fig. 2. The radius of the bubble as a function of time, here we have taken a moving average over 8 actuation cycles $(400 \mu s)$. 
The primary Bjerknes force [6] moves the bubble into the channel because the bubble oscillates in phase with the sound field. When the bubble has grown and has a resonance frequency lower than the characteristic frequency of the printhead, the bubble start to oscillate out of phase with the acoustical field, resulting in a Bjerknes force pushing the bubble towards the pressure node, here the nozzle. This process is shown in figure 3, from [2]. The bubble reaches velocities up to $20 \mathrm{~mm} / \mathrm{s}$ inside the ink channel.

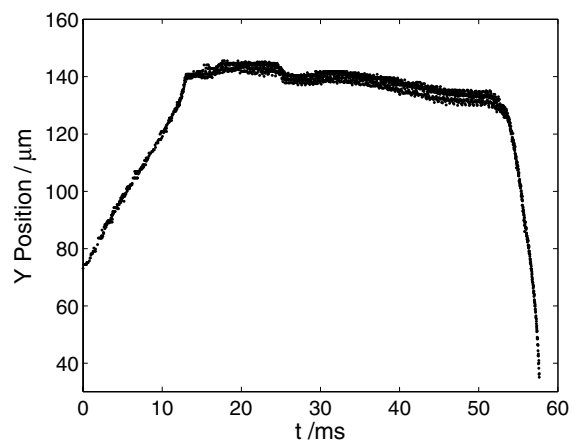

Fig. 3. The displacement of the bubble in the ink channel.

\section{CONCLUSION}

The acoustical signals from the piezo actuator can be used to detect air bubbles inside the printhead. When the air bubble is entrapped it is found that the bubble grows by rectified diffusion due to the acoustic field. The air bubble is moving by the primary Bjerknes force. The direction of the movement is determined by the resonance frequency of the bubble and therefore by its radius.

\section{ACKNOWLEDGMENT}

This study has been financed by the Fundamenteel Onderzoek der Materie (FOM) of The Netherlands under Grant. No. 02MFS39 and by Océ Technologies B.V. We thank the staff of Océ Technologies B.V. for support.

\section{REFERENCES}

[1] J. de Jong, H. Reinten, M. van den Berg, H. Wijshoff, M. Versluis, G. de Bruin and D. Lohse, Air entrapment in piezo-driven inkjet printheads, submitted to JASA, 2005.

[2] J. de Jong, M. Versluis, H. Reinten, M. van den Berg, H. Wijshoff and D. Lohse, Direct observation of entrained air bubbles in piezo-driven inkjet nozzles, in preparation.

[3] C.T. Chin et al, Brandaris 128: a 25 million frames per second digital camera with 128 highly sensitive frames. Review of Scientific Instruments, 74, 5026-5034 (2003).

[4] C. E. Brennen, Cavitation and bubble dynamics, Oxford University Press, Oxford, 1995.

[5] S. Hilgenfeldt, D. Lohse, and M.P. Brenner, Phase diagrams for sonoluminiscescing bubbles, Phys. Fluids 8, pp. 2808-2826, 1996.

[6] T.G. Leighton, The acoustic bubble, Acadamic Press, London, 1994. 